\title{
THE EFFECT OF CHRISTIAN RELIGIOUS EDUCATION (PAK) ON SPECIAL NEEDS (ABK) IN THE INCLUSIVE SCHOOL OF SUKOLILO AREAS IN UNDERSTANDING THE WORD OF GOD
}

\author{
Lilis Setyarini, M.Th., Kasiatin Widianto, M.Th. \\ Sekolah Tinggi Teologi Injili Indonesia Surabaya \\ E-mail:Lilissetyarini@sttii-surabaya.ac.id,.Kasiatinwidianto@sttii-surabaya.ac.id
}

\begin{abstract}
Christian education is important in the family and school environment. There is no exception for schools that accept students / students with special needs. However, it should be noted that the teaching and learning process of Christian education often has problems, especially in public schools. Problems that arise are mainly caused by unpleasant learning conditions, which are caused by not having a permanent learning place. Always moving around, and the place is sometimes not suitable for students to study, such as in a warehouse, in rooms that have never been used, near bathrooms that are not insulated, in the teacher's room, in the library, etc. thus experiencing obstacles in the teaching and learning process. This of course does not meet the maximum yield target. There are also internal barriers, namely from the students themselves. one of them is disabled children, both physically and mentally. The learning process of disabled children cannot run smoothly due to their disability. Based on the hypothesis test there is a relationship and influence of "Christian Religious Education (PAK) with Children with Special Needs (ABK) in Understanding the Word of God." From thetable ANOVA, it was concluded that there was a significant effect of Christian Religious Education (PAK) with Children with Special Needs (ABK) in Understanding the Word of God.
\end{abstract}

Keywords: Christian Religious Education, learning, Understanding

\section{INTRODUCTION}

In writing scientific papers, the author would like to convey information, that this paper is writing about education, especially Christian education in inclusive schools aimed at students with special needs in terms of receiving and understanding the truth of God's Word. As for the background of the problem, why the author discusses this matter are as follows.

\section{Background to the Problem}

One soul is precious before God. This can be known when the first human creation took place. God created man in the image and was like Him (Gen. 1:26). Likewise from the way God created humans is different from creating everything else.
God first formed from the dust of the ground and breathed through his nose, then the man lived (Gen. 2: 7). It does not stop here, humans are also equipped with the attributes that Allah possesses (this is what is meant by a picture and is similar to God), among

them having reason, ratio and reason that makes people able to know His Creator and worship Him . Humans are created to glorify God and to get the highest goals in those praises. Another proof that human beings are valuable as images that are in front of God is when God gives the task to master and conquer the earth. Humans will rule, or rule ... (Gen. 1:26). The author gives another meaning to the Dyrness note that humans are given the trust to cultivate or care for other God's creations (Gen. 
1:28). This proves that humans are precious before God.

One more amazing thing is, when the first man had fallen into sin, He who was Mahamulia regretted that human action, and drove him out of the Garden of Eden (Gen. 3:23). Humans begin to suffer life, and they will be in eternal punishment for the violations they have committed. But God knows what is needed by humans who have fallen into sin; because the sentence does not speak of temporary time, but is a punishment in the eternal sense. Because God loves humans very much, He wants people to survive punishment. He made a promise in Genesis 3:15, for the efforts of human salvation from eternal destruction. This is called the first promise, namely the promise of redemption or provetagelium. And the promise was fulfilled in the person of Jesus Christ who declared himself in human form, willing to be tortured and crucified for the sake of human salvation. According to John 3:16, that God's love is great for humans, and Jesus' sacrifice on salip wood is His greatest work that is only for humans, with one condition that must trust His messenger, the Lord Jesus Christ, as the only Son of God, and God and the Savior of mankind.

The Bible is the Word of God that speaks of the teachings and promises of God for humans, not other creatures. So it is evident that humans are valuable to God. The Word of God is the provisions that are only addressed to humans as His beloved beings, so they can understand and understand God's will that must be done, to guide His people to the place of renewal and purification that is in Jesus Christ, so that the days are increasingly renewed by grace, and a blessing to others.

The Word of God contains the will of God that must be learned by humans. The Word of God can be taught anywhere, and to everyone, from any group, from the lowest level to the highest level, both to normal people (without physical or mental disabilities), or to people who are classified as disabled ( both physical and mental). God wants His word to be preached or taught, not for certain groups of people, but for everyone without exception. It means that everyone has the right to hear and receive the Word of God.

As the Great Commission of the Lord Jesus in Matthew 28: 19-20 says: "Therefore go and make all the nations of my disciples and baptize them in the name of the Father and of the Son and of the Holy Spirit, and teach them to do all that I have commanded you. And know, I am with you always to the end of time. "

From the contents of the verse it is clear, that God does not sort out or specialize the truth of His Word for certain people, but orders to teach it to all nations. So in this case there are no exceptions.

Life in this world varies. Every living thing has a difference, including in humans. Humans can be different in terms of race, class, physical, and mental. There are normal ones, some are defective. But God never saw that difference. What God wants is all human beings from any group glorify Him. Therefore everyone has the right to receive the teaching of His Word, so that they can understand God's will, and do it in their lives. The Word of God is the truth, and that truth will bring the redeemed to please the Lord, for thus will enjoy a life full of peace and joy. The author has said above, that God's Word can be taught anywhere. One of them, the school is a forum for preaching the Word of God through religious studies, especially Christianity, which the author will discuss in this thesis. However, it should be noted that the teaching and learning process of Christian education often has problems, especially in public schools.

Problems that arise are mainly caused by unpleasant learning conditions, which are caused by not having a permanent learning place. Always moving around, and the place is sometimes not suitable for students to study, such as in a warehouse, in rooms that have never been used, near bathrooms that are not insulated, in the teacher's room, in the library, etc. thus experiencing obstacles in the teaching and learning process. This of course does not meet the maximum yield target. This is an external obstacle. While internal barriers are found in the students themselves. For example if a student is in a condition not physically fit, for example experiencing pain, then the learning process will also be disrupted. But if the student has recovered, the learning process returns to normal.

But what about disabled children, physically or mentally? Of course this is also a problem. The learning process of disabled children cannot run smoothly due to their disability. Not because of illness, but indeed this group of children has experienced abnormalities since birth, or it may also be due to other things that interfere with physical and mental development, so that success in learning also experiences obstacles. 
In general, children with disabilities or disabilities are called children with special needs; because it has special characteristics that are different from children in general, and the way of learning has its own characteristics in accordance with the abnormalities they have. These children need special handling in order to achieve successful learning, both in other fields of science in general and / or in the field of Christian education in particular, which equip them to know the life-saving Christ, even though at present they are physically and mentally disabled. But these needy individuals need to be considered spiritually, because they are precious before God despite their disabilities. The Word of God is an important lesson, which can change one's character for the better (2 Tim. 3:16); does not rule out the possibility for children with special needs, which the author will discuss in this thesis. Even though in the world they experience physical and mental conditions that are not as fortunate as others in general, it does not mean that these children have no hope in their lives. They need help or help getting to know the Savior the Lord Jesus Christ more deeply.

Maybe some parents who have children with disabilities, experience deterioration by negative energy created by themselves. So that they will hide their children because of shame, and do not care about the development of their children. Or some people assume that children who experience physical or mental disabilities must be set aside; it is inappropriate to be in the environment of people who are fortunate in their lives. There may be concerns that it will adversely affect normal children.

But that is not the way. Instead, they need to be aware of their needs, which enable children to develop, so they can live well in the midst of society. Besides that, he also has the right to get knowledge in the world of education or go to school. However, not only is science stuffed in general, but the most important thing is guided to love the Lord Jesus who saved him.

Christian education teachers in schools are responsible for this, both for regular or normal children and for children who are not normal (with special needs); although in this case there is a demand for conformity with a predetermined educational curriculum. However, this is not an obstacle for the freedom of the Christian field study teacher to deliver his program in order to achieve the knowledge of God's word optimally. But it is precisely based on the existing curriculum, the word of God can be developed in a practical but directed manner so that it meets the targets imposed in the curriculum. The school where the writer teaches is an inclusive school, which uses a regular curriculum, a modified curriculum and an individualized curriculum in accordance with the abilities and characteristics of the students. An inclusive school is a school that accepts students, both regular students and students who have abnormalities or also called students with special needs. They learn together, and for students with special needs accompanied by a special assistant teacher during the learning process in class. The regular educators or teachers involved in teaching in inclusive schools must be responsible for learning for all students in their class. While special counselors are responsible for providing learning services for children with special needs, both those in regular classes and special classes.

The author, as a teacher of Christian religious education in inclusive schools, was involved in these two positions, namely both as a regular teacher and a tutor specifically for the study of Christian Education. This happens because teachers in the Christian Religious Education field in general are teachers who are not focused on teaching in one school only, but there are some schools that must be served, so they do not have class schedules like the others. Therefore, the schedule of studying Christianity cannot be done per class following the schedule of the Islamic religion, even though there may be only one or two classes that can follow the Islamic schedule, because at that time there was a Christian teacher present.

Habitually, the learning process of Christian Religious Education is carried out several classes simultaneously at the same time, with different student conditions. One group is regular students and the other group is students with disabilities with various abnormalities. For the writer, this is a difficult job, especially in the distribution of material for regular students and students with special needs, in the process of learning together and at the same time; because for students with special needs, the subject matter is not as wide as regular hardware material, but must be more practical but achieve the contents of the regular class material as a whole.

The task of the teacher in this case is to be able to package the material, by separating it well. Similarly, how to explain material to students in different children's conditions (one is disabled, and 
the other is normal) but at the same time, but both parties, both regular students and ABK students can receive and understand the subject matter well. Learning models like this, the authors call it a model of Cooperative Learning with Collaborative methods.

It should be noted as a comparison only, that in the field of study or other subjects in general, children with special needs are accompanied by one teacher in the learning process in the classroom together with regular children. So even though they (regular students and ABK students) learn together in one class, $\mathrm{ABK}$ students can still learn conducively / receive special guidance from their accompanying teacher.

This is different from the learning process for the subjects of Christian Religion. There is no special assistant teacher for ABK students during religious studies. Handling for regular and crew students, concurrently held by one Christian teacher. Learning conditions like this are possible or can certainly not be effective, and the results are not optimal.

The author saw in several other schools, with the same case, it turned out that there was no or even no good handling from the teacher. Even the teaching carried out has not been able to meet the needs of students or not reach the target of learning according to the determined basic competencies. This shows that learning is still not implemented effectively, so that the results achieved are not optimal, even can be said to be very minimal.

Such conditions do need attention. That is why, the writer tries to overcome it by finding the best way for the success of learning. It is the duty of a teacher, to find the best solution in the teaching and learning process, for all problems that may arise, for the success of teaching and produce competent students.

In this thesis, the author will discuss Christian Religious Education carried out in Inclusive Schools with collaborative learning with the same classes; meaning that between regular students and $\mathrm{ABK}$ with the same class can learn together with the same material but with different portions. The author's main highlight is for students with special needs from grade one to grade six.

\section{Problem Identification}

Based on the background of the problem above, problems can arise that can be identified as follows:First, abnormalities of varied students with special needs are an obstacle in understanding the Word of God through religious learning in schools Christian Education (PAK).

Second, inadequate classroom conditions (places of learning) in the teaching and learning process of Christianity in particular, which creates obstacles in understanding God's Word for students with special needs, through Christian Religious Education.

Third, the complex class situation allows failure to reach the target of Christian Religious Education in terms of understanding the Word of God for students with special needs.

\section{RESEARCH METHODOLOGY}

Research is an activity to find, collect, and analyze various facts regarding problems that occur to obtain solutions or solutions to problems found. In researching research methods, so that research activities run smoothly, well, and directed, and provide results as expected by researchers.

The research method is basically a scientific way to obtain data with specific purposes and uses. The type of this study uses quantitative research, by obtaining data from action research as an intervention to solve problems that occur from the limitations of ABK students (Children with Special Needs), which is done by means of classroom observations. As a complete data, questionnaires were distributed to the teachers of Christian Religious Education, with the aim of equating opinions about solving existing problems. The research method used is a quantitative method.

Based on these explanations, direct observations were held, using a collaborative learning model by telling stories. Collaborative learning activities by way of storytelling are what the writer intended as an idea that the writer applied or tried as a classroom action so that students from $\mathrm{ABK}$ groups get intensive treatment and get more effective learning. In this way the author believes that there will be good success for the development of ABK's ability to understand the Word of God, and then apply it to their lives. 


\section{Place and Time of Research The}

Place and time of research is the location where the author carries out observations and research in a certain amount of time. The place and time of the research the author explained as follows.

\section{Research Place The}

Author conducted a major study at the Klampis Ngasem 1N 246 Elementary School, but also conducted research at other elementary schools in one Sukolilo-Surabaya sub-district. In the previous explanation, it was stated that the Christian religious education teacher had an unfocused teaching place in one school, but could teach several schools in one sub-district. Not all of the five schools have Christian students in the ABK category. Schools with ABK students included: Klampis Ngasem I / 246 Elementary School, Klampis Ngasem V Elementary School, Menur Pumpungan Elementary School. Other schools also have ABK students, but these schools are not listed as inclusion schools in the Education Office. More ABK students are found at Klampis Ngasem I / 246 Elementary School, including Christian and Catholic students. The school was recorded at the Education Office as an Inclusion School. Therefore, the authors conducted a study at the Klampis Ngasem I / 246 SDN, which then added research data in other schools.

\section{School Profile of Klampis Ngasem Elementary School I / 246}

Name of school

Ngasem I / 246 Sukolio - Surabaya

Type of school

: SDN Klampis

Service School

No.school statistics

101056013016

NPSN

20533594

Address

: Jl. Arif

Rahman Hakim No. 99-C Sukolilo Surabaya 60117

Accreditation

$:$ A

Number of teachers

consisting of: 40 regular teachers

accompanying teachers (GPK)

Number of students

students, consisting of

students 125 students (ABK)

Area of school
Name of Principal

Mardiningsih, S.Pd., M.Sc.

NIP

196101011982012049

Rank / class

Kindergarten I / IV b

School email

humas_klampis1@yahoo.co.id

School telephone

031-5925762

\section{Population}

Author takes a population of Christian students at Klampis Ngasem Elementary School I / 246, plus other elementary schools in Sukolilo area, among others, Nginden Jangkungan Elementary School I / 247; Klampis Ngasem V SDN; and Menur Pumpungan Elementary School.

\section{Samples}

In this study the authors took samples from elementary school students, especially Christian students in study groups of children with special needs (ABK). The sample consisted of grade one to grade six, which amounted to thirty students with variations in abnormalities and at different levels.

\section{RESEARCH RESULTS}

The researchers reported the results of research in the field by distributing questionnaires or questionnaires to 30 respondents. In the questionnaire instruments have been formulated in the form of statements, namely 25 for variables $\mathrm{X}$ and 25 also for $\mathrm{Y}$ variables Seen from the highest value or the largest number of scores falls on number five (statement - X5) with a total score of 145 and averages amounting to 4.83 . The statement stated, "For the sake of the safety of his soul, children with special needs must be taught the Word of God every day at home and taught to apply it," in other words, respondents or congregations have a good understanding of it, and moreover they have liked do it.

The hypothesis given is that there is a relationship and influence of "Christian Religious Education (PAK) with Children with Special Needs (ABK) in Understanding the Word of God."To prove this hypothesis can be done in two ways, namely correlation test and regression test. 
Descriptive Statistics: "ABK (Children with Special Needs) are not set aside, but also need to get any education, including religious education, as befits other students who are not ABK." Hypothesis test results: there is a relationship and influence of" Christian Religious Education (PAK) with Children with Special Needs (ABK) in Understanding the Word of God."To prove this hypothesis can be done in two ways, namely correlation test and regression test. Correlation test results: Value of correlation between Christian Religious Education Against Children with Special Needs (ABK) in Understanding the Word of God as much as 0.841 . Thus it can be said that there is already a very high relationship between Christian Religious Education and Children with Special Needs (ABK) in Understanding the Word of God. From the results of the correlation test shows a value of 0,000 , meaning that it is smaller than 0.05 , so it can be concluded that there is a relationship between Christian Religious Education and Children with Special Needs (ABK) in Understanding the Word of God is significant.

The correlation coefficient ( $\mathrm{r}$ ) found at 0.841 is included in the "very strong" category, because it lies between the intervals, $0.80-1,000$. So the conclusion is that there is a "very strong" relationship between Christian Religious Education and Children with Special Needs (ABK) in Understanding the Word of God.

The value of the correlation between Christian Religious Education (PAK) and Children with Special Needs (ABK) in Understanding the Word of God is classified as very strong because it is greater than (>0.841) and has a positive value so it can be said that the relationship between Christian Education (PAK) and Children With Special Needs (ABK) In Understanding the Word of God is in the same direction.

The coefficient of determination (KD) seen in thetable column $R$ Square shows a value of 0.708 or equal to $70.8 \%$ (rounded $71 \%$ ), that is from the results $\left(\mathrm{Kd}=\mathrm{r}^{2} \mathrm{x} 100 \%\right)$. This means that the variation changes Children with Special Needs (ABK) In Understanding the Word of God Christian Religious Education (PAK) dipengaruhi by Christian Religious Education (PAK) by $71 \%$, while the remaining $29 \%$ are influenced by other variables or other factors. Table Anova whose purpose is to find out the influence of Christian Religious Education (PAK) on Children with Special Needs (ABK) in Understanding the Word of God. From the tabulation of theresults ANOVA, it can be seen that the Sig. equal to 0,000 smaller than Alpha 0.05 so the hypothesis that there is no relationship between Christian Religious Education (PAK) and Children with Special Needs (ABK) in Understanding the Word of God, is rejected ( $\mathrm{HO}=$ rejected $)$, and concludes that there is influence significant from Christian Religious Education (PAK) with Children with Special Needs (ABK) in Understanding the Word of God.

Based on the Sig table obtained a value of 0,000 <alpha 0.05 indicates that there is a relationship or a positive and significant influence between the variables $\mathrm{X}$ about Christian Religious Education with Y variables Children with Special Needs in Understanding the Word of God, so H1 is accepted.

\section{CONCLUSION}

So it is clear that Christian Religious Education (PAK) is the right tool for ABK students to understand the Word of God, because it shows a positive influence. Thus the conclusion that the writer can convey, that $\mathrm{HO}$ (as a negative result of the influence of PAK) is rejected, while $\mathrm{HI}$ (which is a positive influence of PAK generated), is acceptable because it can make $\mathrm{ABK}$ able to understand God's Word well. So the influence caused by PAK is very strong and positive for the development of ABK's ability to understand God's Word.

Based on the explanation above, this Christian Religious Education is a very appropriate and important tool for ABK students to understand the Word of God as the foundation of life to be applied in all activities.

Children with special needs (ABK), who are mentally and physically handicapped, are not creatures that need to be set aside. They are noble creations that must be respected for their existence and have the right to receive proper education in the field of religion in addition to other sciences. Embedding understanding of God's Word is very necessary for crews. It is also very important to be informed about the Person who saved people, including the $\mathrm{ABK}$.

The limitations of children with special needs, which are caused by physical and mental disorders, are not obstacles that must be avoided, but must be dealt with patiently and diligently, so that the crew is not humbled as a useless creature, but will get the proper appreciation in the community in general; 
because God certainly does not remain silent, God will use them as instruments of His glory. Therefore, the Word of God is important to convey, and then guided continuously to apply it in life.

\section{REFERENCES}

Abdurrahman, Mulyono. Children with Learning Difficulties. Theory, Diagnosis, and Remedial. Jakarta: Publisher Rineka Cipta, 2012.

Cully, Iris V. (P. Siahaan translation Steven Suleeman). Dynamics of Christian Education. Jakarta: PT BPK Gunung Mulia, 2001.

Darmaputera. Perfect Message. Jakarta: PT BPK Gunung Mulia. 2012.

Directorate of Special School Development. Directorate General of Primary and Secondary Education Management. Ministry of National Education 2007. Learning Models and Education for the Implementation of Inclusive Education. PROGRAM PLAN MODEL.

MINISTRY OF EDUCATION. Management Guidelines for Inclusive Primary Education Schools. Tk: tp, 2008.

Dyrness, William. Themes in Old Testament Theology. Poor: Wheat Publisher Mas, 2004.

Damin, Sudarwan. Research Methods for Behavioral Sciences. Jakarta: Publisher of PT Bumi Aksara, 2000.

Daniel, Moehar. Socio-Economic Research Method. Equipped with several usage analysis and guidance tools. Jakarta: Publisher of PT Bumi Aksara, 2003.

Ferguson. Translation of Sucipto. Grow in Grace. Surabaya: Momentum Christian Literature, 1997.

Flecher. Look at the Man (An Approach to Basic Christianity). Jakarta: PT BPK Gunung Mulia, 2007.

Gunarsa. Psychology of Child and Youth Development. Jakarta: PT BPK Gunung Mulia, 1983.
Geniofam. Parenting \& Success of Children with Special Needs. Jogjakarta: Garailmu Publisher, 2010.

Heydarpoor, Mahnaz. (Fauzi's translator). Love in Christianity and the Foundation of Religious Ethics for Religious People. Surabaya: Eureka Library, 2004.

Kemmis in Riyanto, Yatim. Educational Research Methodology. Surabaya: SIC Publishers, 2011.

\section{KBBI http://kbbi.web.id/p}

influenced Lativa, Eva. Introduction to Educational Psychology. Yogyakarta: PT. Madan Madrasah Library. Member of IKAPI, 2012.

Lebar, Lois. Education That Is Christian (Christian Mangajar Learning Process and

Biblical Curilulum). Malang: Wheat Publisher Mas, 2006.

Mello. (Translated by Wartaya). Called to Love. Yogyakarta: KANISIUS Publisher (Member of IKAPI), 1994.

Rising. Become a Whole Person. Yogyakarta: KANISIUS, 1999.

Milne, Bruce. Recognizing the Truth (Guide to the Christian Faith). Jakarta: Publisher PT. Gunung Mulia BPK, 2011.

Muhari. Fundamentals of Educational Sciences. Surabaya: State University, 2004.

Nainggolan. Become a teacher of Christianity. (An Effort to Improve the Quality and Quality of Teacher Professions). Kindergarten: Generasi Info Media, 2007.

Nasution. Educational Sociology. Jakarta: PT. Bumi Aksara, 1994.

Nerius, Juliana. Guide to Christian School Teachers (Practical ideas for everyday use. Kindergarten: ACCI Indonesia publisher, 2005.

Nuhamara, Daniel. Christian education. Kindergarten: Bina Media Informasi, 2005.

PAK Advisor. Bandung: Info Media Journal Publisher, 2007. 
Nuraeni. Early Intervention for Problem Children. Jakarta: Publisher Rineka Cipta, 1997.

Nurkholis. School Based Management. Jakarta: Publisher PT. Grasindo, 2006.

NAKITA. Understand and deal with Children with Special Needs (Celebration Palsy). Tk: Publisher of PT Sarana Kinasih Satya Sejati, 2002.

Nana, Syaodih. Educational Process Psychology Foundation. Bandung: PT Remaja Publisher Rosdakarya, tt

Plaisier, Arie. Human Image of God. Breakthroughs in the Field of Christian Anthropology. Jakarta: PT. BPK Gunung Mulia, 2002.

Prawira, Atmaja. Educational Psychology in a New Perspective. Jogjakarta: Publisher Ar - Ruzz Media, 2012.

Management of the Center for Christian Education Development (P3K) Salatiga. The Christian Religious Education Symposium (PAK) at the School. Center for the Development of Christian Education in Salatiga 1988.

Ruup, Anne Neufeld. Ismail Banne's translation. Growth and Development with Children Lead Children to Emotional Growth, Moral Faith. Jakarta: BPK Gunung Mulia, 2009.

Siahaan, Ranto Sari. Change to Fruit. Yogyakarta: ANDI Publisher, 2010.

Smart, Aqila. Children with disabilities are not apocalypse. Learning Methods and Therapy for Children with Special Needs. Yogyakarta: KATAHATI Publishers, 2010.

Sukarso, Ekodjatmiko.Management Guidelines for Inclusive Primary Education Schools. Directorate of Special School Development, Directorate General of Primary and Secondary Education Management at the Ministry of National Education. 2008.

Santoso, Ananda. Complete Indonesian dictionary for elementary, junior high, high school \& general. Surabaya: ALUMNI Publishers, tt

Sulistyono, Edy. Demon Shooting Strategic Target Children. Yogyakarta: Penerbit ANDI, 2010.
Sidjabat. Mengajar secara Profesional. Bandung: Yayasan Kalam Hidup, 2011.

Sukmadinata, Nana Syaodih."Landasan Psikologi Proses Pendidikan”. Bandung: PT Remaja Rosda karya. 2003.

Subini, Nini. Panduan Mendidik Anak dengan Kecerdasan Di bawah Rata-rata. Jogjakarta: Jasalitera, 2012.

Sugiyono. Metode Penelitan Kuantitatif, Kualitatif dan $R \& D$. Bandung; Penerbit Alfabeta, 2011.

Tim Dosen FIP Universitas Negeri Surabaya. Pengantar Ilmu Pendidikan. Surabaya: tp, 2004.

Veskarisyanti, Galih. 12 Terapi Autis Paling Efektif \& Hemat (Untuk Autisme, Hiperaktif, dan Retardasi Mental). Yogyakarta : Penerbit Pustaka Anggrek (Anggota IKAPI), tt

Walvoord, John F. The Moody Bible Institute of Chicago (Terjemahan Cahya R.). "Yesus Kristus Tuhan Kita. Surabaya: Penerbit YAKIN, 1969.

Wahyudi, Imam. Mengejar Profesionalisme Guru. (Strategi praktis mewujudkan citra guru profesional). Tk: Prestasi Pustaka Publisher, 2012.

Yatim, Riyanto. Metodologi Penelitian Pendidikan. Surabaya: Penerbit SIC, 2011.

Zuriah, Nurul. Metodologi Penelitian Sosial dan Pendidikan Teori-Aplikasi. Jakarta: PT Bumi Aksara, 2007. 